\title{
Aspectos das Viagens Medievais: obstáculos e perigos
}

Jônatas Batista Neto

Departamento de História - FFLCH/USP

Até o ano de 1580 , quando Montaigne iniciou a redação do seu Journal de Voyage en Italie, a literatura européia de viagem sempre insistiu nos aspectos negativos das missões. De fato, para o homem medieval, viagem é, antes de tudo, sofrimento. Nada ilustra melhor essa atitude do que a etimologia da palavra inglesa travel. Usada comumente para designar esse tipo de expedição, ela é uma evolução de tria palus, instrumento de tortura de tempos romanos, passando pela forma travail, que indica agonia, dor intensa, sofrimento (1).

Os textos medievais, que negligenciam, frequentemente, os aspectos quotidianos das missões, contém várias referências aos perigos dos caminhos, tais como, por ex., a neve das montanhas ou, pelo contrário, o calor excessivo das regiões meridionais, as doenças, os ataques dos animais e dos homens, etc. A frequente conjugação de todos esses problemas levou Jean-Paul Roux a caracterizar a rota medieval da seguinte maneira:

"Uma palavra a resume e a define: o perigo. Por toda parte, no seu percurso, riscos, a incerteza do amanhã. Perigo dos homens, perigo da natureza, rigores do clima, privação. Perigos previstos, imaginados, temidos mas aceitos; nos primeiros tempos misteriosos, desconhecidos, depois, quando se está mais bem informado pelos que retornaram, perigos avaliados, medidos, analisados, menos temidos porque se sabe mais como prevervar-se. Iguais de resto dos dois lados, no Extremo-Oriente e no Ocidente, mais agudos somente no no man's land que os separa" (2).

De fato, com frequência, a rota é mesmo muito cruel para o peregrino e diversos exemplos podem ser recolhidos em várias fontes para ilustrar a

(1) - Cf. o verbete Travel de The Oxford English Dictionary. Oxford, 1933.

(2) - Les Explorateurs au Moyen Age. Paris, 1967, p. 87. 
atmosfera de angústia e de terror em que vivia o homo viator. Embora escrita no séc. VI, a oração de Gildas "pro Itineris et Navigii Prosperitate" apresenta $\circ$ quadro dos perigos que rondavam o viajante medieval e que, mesmo que não tenha sido repetida pelos séculos afora, deve ter-se reproduzido, sob diversas formas, na mente dos peregrinos. O trecho que apresentamos abaixo dá uma boa idéia da quantidade e da variedade dos riscos a que se submetiam os exploradores medievais.

Ne me captent
Ne (que) fures
Ne me unde
Neque aquae
Ne tenebris
Velis plenis
Maris cunctis
Christus mecum
Vincat terre
Vincat tela
Vincat cuncta
Vincat quoque
Vincat saeva
Ut haec cuncta
Neque meis
Sanus ego
Sine damno
Sana nave
Sanis equis
Sana nostra
Ut sit apta
Inimici
Quamvis mala
Christi mihi
Vie cuncte
Si ascendam
Si descendam
Si camporum
(Si) silvarum
Via plana
Usque loci

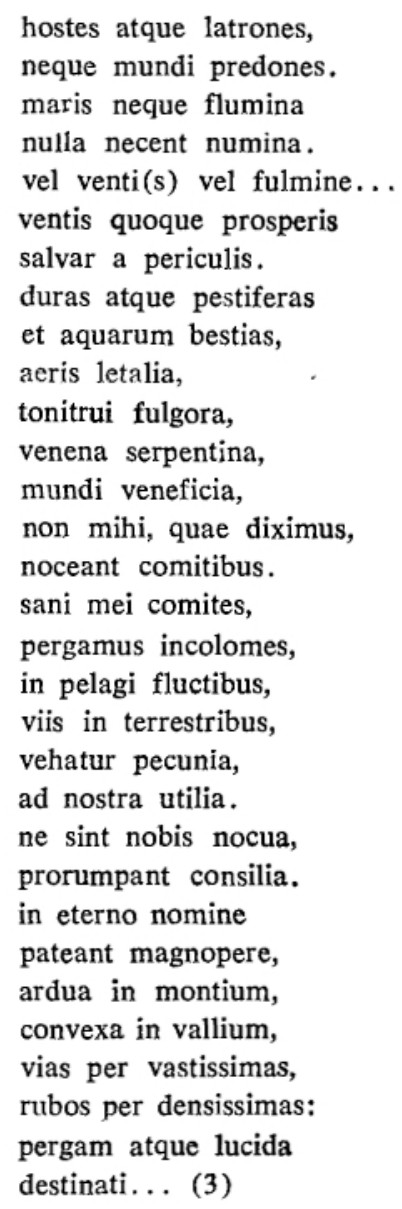

De qualquer maneira, os homens dos séc. XI, XII e XIII amaram apaixonadamente essas viagens, fossem elas destinadas a levá-los a Com.

(3) - in Monumenta Germaniae Historica, Poetae Latini, IV, 2, pp. 618-9. 
postela, a Roma ou à Terra Santa. A peregrinação à Espanha, ligada ao processo de expansão cristã conhecido por Reconquista, teve tal sucesso que, em 1139, redigiu-se um precioso "Guia do Peregrino". Quanto às expedições à Terra Santa que, a partir de 1096, se transformam nas Cruzadas, acreditamos sejam dispensáveis os comentários. Émile Mâle disse que os peregrinos desse tempo, além das realidades duras e frequentemente sórdidas da rota, reencontravam o sentido profundo da sua fé. São indiscutivelmente inspiradas estas suas palavras:

"Os homens do século XII amaram apaixonadamente esssa grandes viagens. Parecia thes que a vida do peregrino era a própria vida do cristão. Pois o que é um cristão senão um eterne viajante que não se sente em casa em parte alguma, um viajante em marcha para uma nova Jerusalém" (4).

Não obstante, se os relatos de riscos e acidentes abundam nos, textos medievais, as referências aos pormenores das longas e penosas viagens são poucas. Dificilmente encontramos informações relacionadas com gastos, transporte e obtenção de dinheiro, alojamento, alimentação, cavalos, etc. . Todavia, graças a alusões que aparecem nas fontes, podemos concluir que os viajantes passavam as noites em hospedarias (hospitia) e em mosteiros. Alguns dos hospícios - os situados em pontos de passagem muito frequentados - adquiriram certo destaque.

Em meados do séc. XII, o Grande São Bernardo, um dos dois mais famosos passos dos Alpes, ganhou a sua hospedaria, fundada por Bernardo, arcediago de Aosta. Situado entre os territórios do Império e a Lombardia, o Grande São Bernardo, ao contrário do Monte Cenis, recebia normalmente os viajantes provenientes da Renânia e da Basiléia, os que afluíam do Franche-Comté, os que vinham dos territórios cortados pelo Ain e pelo Saône, e os que partiam da Sabóia.

Já em tempos romanos tinha sido construída uma estrada nessa passagem situada a 2.472 metros de altura. Foi erguido também, no próprio desfiladeiro, um templo dedicado a Júpiter. Em 1125, aparece o hospício medieval dedicado a Nicolau de Myre. Vinte e quatro anos depois, já canonizado, o arcediago Bernardo, fundador da hospedaria, foi acrescentado a esse patronato. $\mathrm{O}$ antigo nome de Mons Jovis, associado à divindade cultuada no local, foi substituído por São Bernardo, ao qual se anexou o adjetivo Grande para diferenciá-lo do Pequeno São Bernardo, situado mais a oeste.

A manutenção do hospício era garantida pelos cônegos regulares de Santo Agostinho, dos quais dependia a abadia de Agaune, localizada na

(4) - apud J. Le Goff, Le Moyen- Age, 1060-1330. Paris, 1968, p. 50. 
saída setentrional da rota. Durante toda a Idade Média, em consequência do tráfego, que aumentava continuamente, houve necessidade de sucessivas ampliações, que se prolongaram pela Idade Moderna, até o grande incêndio de 1555. Naturalmente, a hospedaria era um edifício sólido, construído para desafiar as intempéries e para resistir às avalanchas (5).

Os textos são mais pródigos quando se trata de descrever os contra. tempos das viagens. João de Cantuária, hospedado no Grande São Ber. nardo, escreveu, para o seu mosteiro, uma carta na qual se queixa do frio intenso. Tão baixa estava a temperatura que o pobre monge não podia andar sobre a superfície gelada do pavimento, sua barba tinha endurecido, seus dedos recusavam-se a obedecê-lo e até a tinta, que ele transportavai na sacola, tinha-se transformado numa seca massa de gelo. Tomado de angústia, o viajante inglês contemplava os vales e as montanhas e dirigia a Deus uma oração, dizendo:

\section{"Devolve-me à companhia de meus irmãos, para que eu possa dizer-lhes que nunca venham a este lugar de tormento!" (6).}

Os padecimentos do monge de Cantuária assemelham-se bastante aos de Ibn Batuta na Ásia Central. Como muitos exploradores medievais, em vários pontos do mundo, o viajante marroquino passou também por invernos terríveis. Sua descrição desses sofrimentos, quase idêntica à de João de Cantuária, evoca igualmente o desamparo do homem diante da natureza inclemente:

"Eu vestia três peliças de lã e duas ceroulas, uma das quais dupla; nos pés, botinas de lã, um outro par de linho duplo e um terceiro de couro de cavalo, forrado com peles de lobo. Eu não podia montar a cavalo sozinho por causa desse grande número de roupas. Eu me lavava com água quente, perto do fogo, mas a água gelava instantaneamente" (7).

Um eloquente relato das dificuldades enfrentadas pelos viajantes, ao passarem pelos Alpes, nos é fornecido por Lamberto de Hersfeld, quando descreve a travessia do Monte Cenis pelo Imperador Henrique IV, em janeiro de 1077. Como o inverno, naquele ano, se mostrasse muito severo, o famoso passo alpino se encheu de massas de neve e de gelo. Foi necessário, portanto, contratar guias locais para orientar a comitiva e evitar os pontos ingremes e os terrenos escorregadios. Mesmo assim, a viagem não se tornou muito mais fácil e, com frequência, os cavaleiros e pedestres

(5) - V. Raymond Oursel, Les Pelerins du Moyen Age. Paris, 1963, pp. 67-9

(6) - Epistolae Cantuarienses, $\mathrm{n}^{\circ}$ 197, fevereiro de 1188, traduzida por W. Stubbs, Seventeen Lectures. Oxford, 1886, p. 128.

(7) - Jean-Paul Roux, op. cit., pp. 92-3. 
tiveram de recorrer a complicados expedientes para superar os obstáculos que se apresentavam no trajeto. Foi preciso rastejar, agarrar-se aos guias, saltar e até mesmo rolar por encostas geladas; a rainha e as outras damas foram postas em sacos de couro de boi para que os guias pudessem descêtlas de certas colinas. Também foram usados expedientes para transportar os cavalos (8).

Outras referências aos perigos da travessia dos Alpes no inverno e, consequentemente, aos terrores que assaltavam os viajantes podem ser encontradas nas Gesta Abbatum Trudonensium, quando da passagem do Grande São Bernardo, em 1128, por Rodolfo, abade de St. Trond, e Alexandre, bispo de Liège (9) .

Após terem celebrado o Natal em Placência, os dois eclesiásticos seguiram para Aosta e, daí, para Restópolis (Etroubles), aldeia situada ao pé do Mons Jovis. Para prosseguir e cruzar o passo, Rodolfo e Alexandre se viram obrigados a contratar guias, com os quais caminharam $16 \mathrm{Km}$, até alcançarem St. Rémy, cidadezinha erguida na própria montanha. É interessante observar que o texto faz referência à presença de um grande número de viajantes nesse lugar. Isso mostra que, mesmo no inverno, os passos alpinos eram bastante frequentados e que, apesar de atemorizarem totalmente de lá (10).

Os guias que se apresentaram aos viajantes reunidos em St. Rémy, entre os quais estavam os já mencionados Rodolfo e Alexandre, usavam gorros de feltro, luvas de lã e botas munidas de pontas de ferro. Exigiram um alto preço e prometeram conduzir os viajantes e seus cavalos pela difícil passagem. Mas, logo que saíram da aldeia, foram sepultados por enormes massas de gelo. Os aldeões, que acorreram ao local da catástrofe, conseguiram retirar alguns deles com vida, mas muitos já estavam mortos quando chegaram os socorros. Aterrorizados com o evento, os peregrinos retornaram a Etroubles, onde aguardaram que o tempo melhorasse. Só mais tarde, e novamente com o auxílio de guias, eles se arriscaram a cruzar o ameaçador São Bernardo.

A passagem das Gesta Abbatum Trudonensium que trata desses acon. tecimentos faz diversas alusões ao medo que os caminhantes sentiam dian. te das montanhas. Quando se preparavam para a travessia que foi impedida pelo acidente com os guias, os viajantes estavam tão certos da própria morte que o Padre de St. Rémy não foi suficiente para atender a todos e

(8) - Lambertus Hersfeldensis, Annales in Migne, Patrologia Latina, 146 cols. 1235-6.

(9) - Gesta Abbatum Trudonensium in Monumenta Germaniae Historica "Scriptores", X, p. 307.

(10) - Idem, ibidem . 
eles se confessaram uns aos outros em volta da igreja. Também merece destaque a referência aos "profanos recintos de Jove" (11), que aparece nessa fonte. A leitura do texto nos dá a impressão de que, para os peregrinos, aquelas montanhas ainda são o reino da antiga divindade olímpica. Apesar de destronado, Júpiter está sempre pronto para descarregar a sua fúria sobre os cristãos .

Os perigos e obstáculos que o homem medieval encontrava na barreira dos Alpes eram sempre os mesmos, independentemente da passagm escolhida para entrar na Itália. Em 1437, após cruzar as montanhas pelo São Gotardo, o peregrino espanhol Pero Tafur pôde escrever o seguinte:

"No terceiro dia após ter deixado Milão, cheguei a uma cidade alemã onde todos os meus animais e a minha bagagem foram postos em barcos, os quais, a seguir, cruzaram um grande lago que recebe as suas águas dos Alpes... No dia seguinte, eu parti e cheguei ao pé do passo São Gotardo, no alto dos Alpes. No dia seguinte, depois que os necessários preparativos já tinham sido feitos, nós demos início à subida. Era então o fim de agosto e a neve estava derretendo com o calor, o que fazia com que a travessia fosse extremamente perigosa. As pessoas daquela região usam bois que estão acostumados com a trilha. Um deles vai na frente, arrastando, por uma longa corda, um reboque que parece com uma debulhadora castelhana. $O$ passageiro senta sobre ele enquanto o seu cavalo, seguro por uma rédea, segue atrás. Se acontece algum acidente, só o boi é envolviđo. Antes que alguém entre no estreito desfiladeiro, disparam-se armas de fogo para fazer cair, das montanhas, qualquer bloco de neve solto, porque, às vezes, essas avalanchas sepultam os viajantes... As montanhas são densamente povoadas, as hospedarias e pequenas aldeias são numerosas (12).

Outros perigos e outras situações aflitivas suportados nas viagens à Itália aparecem no registro da missão de João de Oxford à Sicília, no verão de 1176 , que teve por finalidade negociar o casamento da princesa inglesa Joana com o soberano franco-normando Guillherme II. O relato dos acontecimentos, incluído por Radulfo de Diceto no seu Ymagines Historiarum, é bastante pormenorizado e parece ter sido feito pelo próprio João, bispo de Norwich, ao cronista mencionado. No seu trajeto, o viajante passou por regióes que sofriam com a falta de alimentos para os homens e para os animais. No Auvergne, por ex., o bispo ficou impressionado com a quantidade de pessoas famintas que enchiam as ruas e se lamentavam (13).

(11) - Idem, ibidem.

(12) - Cit. por M. Rowling, Everyday Life in Medieval Times. Londres, 1969, pp. 95-6.

(13) - Rolls ed., I, pp. 416-7, traduzido por G. B. Parks, The English Traveler to Italy. Roma, 1954, p. 198. 
Entretanto, a fome, que, com certeza, atormentou muitos exploradores não é um tema frequente na literatura de viagem inglesa da época. Nesse sentido, os textos dos ocidentais que atravessaram parte do Continente Asiático no séc. XIII, como, por ex., Guilherme de Rubruck e Giovanni dal Piano di Carpine, são muito mais eloquentes. O primeiro diz:

"Nós passamos um bom mês suportando tal fome e sede que nós poderíamos apenas permanecer vivos porque o alimento preparado para quatro era adequado para um (14).

E o segundo chegou a consagrar todo um capítulo da sua obra, o de número XXII, "à sede, à fome e outras misérias que eles tiveram de suportar" (15). Somos levados a concluir, então, que nesse aspecto das condições materiais das viagens, os peregrinos que seguiram para a Itália gozavam de uma relativa segurança. Espectador do sofrimento de populações famintas, o nosso João de Oxford não se refere à fome como uma privação pela qual tenha passado. Os seus maiores problemas deveriam aparecer quando, deixando os cavalos em Gênova, embarcou para a Itália meridional.

Como as embarcações não fossem suficientemente seguras, o mar era sempre uma fonte de perigos para o homem medieval. Além disso, apresença de piratas no Tirreno, hem como em outros pontos do Mediterrâneo, aumentava a insegurança do viajante. Radulfo de Diceto menciona também a sujeira dos remadores, cujo odor provocava náusea e, muito especialmente, o forte calor que, para os peregrinos provenientes do norte da Europa, deveria ser quase intolerável.

Não é de admirar-se, portanto, que os membros dessa missão tenham caído doente, logo que chegaram à Sicília. Somente o bispo de Norwich pôde retornar à Provença e à Inglaterra no outono daquele mesmo ano. Quanto a princesa, que fez a mesma viagem para tornar-se soberana do reino franco-normando da Sicília, sabemos que, uma vez em Nápoles, decidiuse a seguir por terra, porque o trajeto por mar tinha-se tornado insuportável.

Outros problemas das viagens por mar aperecem na narrativa das aventuras de Roberto da Normandia e de seu exército, formado por ingleses, normandos e bretões, no ano de 1096. Já em Roma, muitos elementos fizeram defecção e o número dos cruzados diminuiu bastante. Em Bari, os remanescentes não puderam embarcar: como o inverno se aproximasse, os marinheiros se recusavam a aventurar-se na travessia do Adriático. Assim, Roberto foi obrigado a deslocar-se para a Calábria, onde passou o

(14) - Cit. por J. P. Roux, op. cit., p. 94.

(15) - Idem, ibidem. 
inverno de 1096-7. Durante esse período de espera, desesperançados e temerosos de que seu dinheiro acabasse, diversos cruzados trocaram as suas armas por bastões de peregrinos e retornaram à Normandia (16).

Em 1097, o reduzido exército do duque Roberto seguiu para Bari. Lá os soldados foram surpreendidos pelo espetáculo de um naufrágio. Sem razão aparente, um navio dividiu-se em duas partes, perto da praia. Nesse acidente morreram 400 pessoas, cavalos e mulas se afogaram e muitos bens se perderam. Naturalmente, após presenciarem o desastre, os companheiros de Roberto da Normandia ficaram extremamente amedrontados diante da perspectiva de embarcar e atravessar o mar. Todavia, a despeito da desistência de alguns elementos que, jurando nunca mais arriscar a vida em viagens desse tipo, abandonaram a companhia, a passagem do Adriático foi feita. Como não houvesse vento, o navio ficou parado durante três dias mas, no quarto, conseguiu atingir a costa a dez milhas de Durazzo. Da costa oriental do Adriático, os cruzados seguiram para Terra Santa, pela Bulgária (17).

Uma das mais sérias inimigas dos viajantes era a doença. Em 1188, alguns monges de Cantuária pereceram em Roma, vítimas de uma peste que assolava a cidade. Gervásio de Cantuária nos diz que a terrível doença era consequência do calor do verão e das várias afecções do ar que aparecem logo após o dia de São João (18). Cerca de mil pessoas - entre as quais diversos estrangeiros em visita à cidade de Roma - morreram nessa ocasião. Dentre os elementos que participavam da missão proveniente da Inglaterra, cinco monges foram vitimados mas a moléstia tomou conta de todos e mostrou-se tão forte que eles, enfraquecidos, não podiam nem mesmo oferecer água aos companheiros acamados (19).

Entre os que faleceram estava o prior Honório que, dias antes de sua morte, graças aos esforços do bispo de Óstia, fora levado para Velletri, cuja atmosfera mais pura era considerada benéfica para a saúde. A despeito dessa medida, o prior teve o mesmo destino dos cincos monges mortos em julho. Diz Gervásio de Cantuária que o fato de os ingleses terem sido convenientemente sepultados em diferentes igrejas de Roma pode ser considerado uma manifestação do favor divino porque o número de mortos era tão alto que toda a população, incluindo elementos da nobreza, lutavam para obtenção de um lugar para os setıs familiares nos cemitérios (20).

(16) - Fulchri Carnotensis, Historia Hierosolymitana, I (VII, VIII), p. 167, ed. por H. Hagenmeyer, 1913; ibidem .

(17) - V. também L. F. Salzman, English Life in the Middle Ages. Oxford, 1950, pp. 280-1.

(18) - Opera Historica, I, pp. $428-9$ in Parks, op. cit., p. 200.

(19) - Ibidem.

(20) - Ibidem. 
A violência humana, decorrente dos conflitos políticos, é um dos males que aparecem com mais frequência nos textos dos viajantes medievais (21). Tendo em vista que a Itália foi o teatro da mais célebre luta pelo poder na Idade Média - a que envolveu os imperadores e os papas -, e que o fracionamento político da península, nesse período, dava origem a inúmeras hostilidades menores, ligadas ou não à luta entre as duas autoridade máximas da Cristandade, a situação dos peregrinos que deviam atravessar esse país era sempre de grande insegurança.

Em 1161, Sansão, que, mais tarde, deveria tornar-se abade de Bury, acompanhado por Roger de Hingham, levou a Roma um apelo dos monges dessa localidade. Como, nessa ocasião, a Itália estivesse agitada pela contenda entre Alexandre III e Frederico Barbarruiva, que, inclusive, estava dando o seu apoio a um anti-papa, os viajantes que transportavam cartas ao papa corriam sérios perigos: alguns foram aprisionados, outros enforcados, outros ainda tiveram os setıs lábios a narizes cortados e foram enviados, mutilados, ao pontífice. Eis como o monge de Bury escapou a toda essa violência.

"Eu fingi ser escocês, pus um traje escocês e portei-me à maneira dos escoceses, chegando a lançar o meu bastão como um dardo contra os que me ridicularizavam e pronunciando palavras ameaçadoras à maneira dos escoceses. E quando os que me encontravam perguntavam quem eu era, eu somente respondia: "Ride, ride Rome, turne CantWereberei" ("Cavalgo, cavalgo Roma, volto Cantuária"). Assim fiz eu no sentdo de disfarçar a mim e ao meu objetivo, de maneira que de forma mais segura, pudesse seguir o caminho para Roma. E após ter obtido cartas do Papa tal como desejava, no meu retorno de Roma, ao passar por um certo castelo, eis que os servos da fortaleza me cercam e me detém, dizendo: "Este viajante solitário, que finge ser escocês, ou é um espião ou transporta cartas do falso Papa Alexandre". $\mathrm{E}$, enquanto revistavam meus farrapos, botas, ceroulas e até meus velhos sapatos, que eu carregava dependurados sobre os ombros como os escoceses, enfiei' a mão na sacola de couro que continha a missiva do Papa, escondida sob uma pequena taça, que eu costumava usar para beber e, graças a Deus e a Santo Edmundo, puxei juntamente a carta e a taça, de maneira que, quando ergui o braço, segurava a primeira sob a segunda. Eles viram a taça mas não a carta. E assim, escapei deles em nome do Senhor. Eles me tomaram todas as moedas que possuía, de sorte que tive de recorrer à mendicância de porta em porta, quase sem dinheiro para utilizar, até minha chegada à Inglaterra" (22).

(21) - Um bom estudo desse problema pode ser encontrado em J. J. Jusserand, English Wayfaring Life in the Middle Ages. Londres, 1950, pp. 72-89.

(22) - Cronica Jocelini de Brakelonda de rebus gestis Samsonis abbatis monasterii Sancti Edmundi. "Nelson Medieval Classics". Londres, 1951, pp. 48-9. 
As agitações políticas eram, portanto, fonte de constante violência. Todavia, esta podia aparecer também sob a forma mais prosaica de ação de salteadores e de ambição dos potentados locais que, em certas ocasiões, se comportavam como ladrões comuns. Eadmer nos conta como Anselmo de Cantuária, depois de receber homenagens da parte de leigos e de monges, em território francês, escapou, graças à sua forte personalidade e presença de espírito, à violência do duque da Borgonha, o qual, informado de que o viajante transportava muito dinheiro, tinha reunido um bando de guerreiros para abordá-lo e assaltá-lo (23).

Os riscos de um ataque aumentaram muito quando Anselmo chegou a Lião; a essa altura, já se tinha espalhado o boato de que o arcebispo de Cantuária transportava ouro e prata, na sua viagem a Roma. Assim, diversos foram os senhores locais que passaram a vigiar as estradas, incumbiram espiões de obter informações e imaginaram armadilhas para capturá-lo. Entre estes estavam senhores do Império, excitados pela hostilidades entre seu soberano e o papa e Wibert, antigo arcebispo de Ravena, que, para vingar-se de ter sido expulso de sua sé, dedicava-se a capturar, roubar e humilhar bispos, monges e padres que passavam por suas terras.

Anselmo parmaneceu bom tempo em Lião, esperando pela volta dos mensageiros que tinha enviado a Roma. Antes que estes retornassem, o grupo de peregrinos, compostos apenas de três elementos - o arcebispo, o monge Balduíno e o cronista Eadmer - não saiu de Lião, meśmo porque Anselmo caíra doente e foi preciso cercá-lo de cuidados. Com a demora, surgiu e difundiu-se o boato de que, temeroso e enfraquecido por uma moléstia, o arcebispo de Cantuária não iria arriscar-se a entrar na Itália.

Quando os mensageiros retornaram, Anselmo foi informado de que o papa o aguardava com ansiedade. Assim, os três monges deixaram Lião, três dias após o Domingo de Ramos, e cruzaram os Alpes pelo Monte Cenis. Em Aspera, ao pedirem alojamento e alimentação por uma noite, após terem comunicado que eles eram peregrinos seguindo para Roma, receberam, dos monges da aldeia, uma curiosa resposta. Segundo eles, nenhum clérigo conseguiria prosseguir naquela direção sem ser molestado. Exemplificando, disseram que o próprio arcebispo de Cantuária, após ter chegado a Placência e sabido dos perigos que o aguardavam no resto da jornada, tinha mudado de idéia, retornando à França e ainda estava esperando em Lião (24).

A despeito da advertência, o arcebispo e seus dois companheiros prosseguiram viagem e atingiram o seu objetivo. Os perigos anteriores mencionados já se tinham desvanecido porque não se acreditava mais que Ansel-

(23) - Eadmeri Historia Novorum in Patrologia Latina, 159, cols) 403-4.

(24) - Idem, ibidem, cols. 404-8. 
mo persistisse no seu intento. Em Roma, onde chegaram sem maiores problemas, os três foram acolhidos pelo papa e permaneceram quatro dias hospedados no palácio de Latrão.

Por terra ou por mar, o viajante era obrigado a enfrentar um concerto de dificuladdes e de perigos. Ao risco de morte nos passos alpinos, somavam-se aescassez de alimentos, a falta de boas acomodações ,os naufrágios, os ataques de piratas, a inadequada higiene, o excesso de calor, etc.

No relato da viagem do arcebispo Ricardo, sucessor de Thomas Becket, a Roma, Radulfo de Diceto faz uma espécie de síntese do sobstáculos que apareciam nas estradas medievais. Após transportar a barreira dos Alpes, ele teve de enfrentar, na Itália setentrional, complôs de cismáticos e epidemias e, após o seu embarque em Gênova, com destino a Roma, a fúria do mar, as tempestades e os ataques de piratas (25).

Essa síntese cristã equivale ao quadro apresentado para o mundo islâmico pelo geógrafo muçulmano al-Muqaddisi, e que é resumido por T. W. Arnold da seguinte maneira:

“...ele próprio teve imensa dificuldade de obter, em cada localidade, informação correta relativa ao clima, aos produtos, situação do comércio, cunhagem de moedas, pesos e medidas e as características gerais dos habĭtantes. Misturou-se com gente de todas as classes $\mathrm{e}$ nos conta como conseguiu audiência com príncipes e familiaridade com os grandes, enquanto em outros momentos teve de ganhar a vida precariamente, mascateando no bazar ou encadernando livros. Por vezes podia dar-se o luxa de cavalgar ou ser transportado em palanquim; em outras ocasiões teve de caminhar sob o sol ardente ou na neve. Sua caravana foi pilhada diversas vezes por salteadores de estrada e, uma vez, ele quase se afogou. Foi lançado na prisão como espião, foi acusado de heresia injustamente, sofreu humilhações de toda sorte e teve muitos encontros desagradáveis com ladrões e salteadores. Nunca chegou a ter de mendigar seu pão mas deve ter passado perto desse extremo. Jantou com os Sufis, dividindo o escasso alimento dos ascéticos, presidiu o culto público na mesquita, pregou do púlpito e, do minarete, chamou o povo à oração. Observou galés bizantinas envolvidas numa batalha naval e incorporou-se a expedição militares em outras fronteiras. Durante essas viagens, al-Muqaddisi nos conta que recebeu 30 denominações diferentes, como peregrino, asceta, leitor do Corão, professor, advogado, encadernador, fabricante de papel, médico, mensageiro e outros"' (26).

(25) - Ymagines Historiarum, I, pp. $387-8$ cit. por G. B. Parks, op cit., p. 206

(26) - in Travel and Travellers of the Middle Ages. Londres, 1930, p. 97. 
Como se pode depreender do relato desse viajante, as dificuldades materiais eram mais ou menos as mesmas tanto em território da Europa ocidental quanto no vasto mundo árabe.

Não satisfeito com a variedade das dificuldades materiais reais, os cronistas, com frequência, acrescentam riscos imaginários. Assim, numa outra passagem, o mesmo Radulfo de Diceto associa as viagens por mar à tumultuada fuga dos troianos para a Itália após o saque da cidade e nos diz que João de Oxford conseguiu escapar aos rochedos e redemoinhos de Cila e Caribde (27).

Entre os perigos fantásticos, criados pela imaginação humana, os viajantes costumam incluir as ameaças de fantasmas, que frequentam zonas pouco ocupadas pelo homem como, por ex., florestas, montanhas e desertos. No que diz respeito à Itália, a região mais temida era mesmo a da barreira dos Alpes. A propósito do difundido receio do viajante medieval diante desse obstáculo natural, lembra H.S. Bennett:

"A desgastante ascensão das encostas setentrionais dos Alpes tornava-se ainda mais temível para o viajante medieval por sua crença de que esses espaços desabitados eram o refúgio predileto das criaturas do Demônio, e ele deve ter alcançado os passos mais elevados e contemplado a Itália com um certo alívio - um alívio frequentemente acelerado pela dramática natureza da mudança que ainda hoje acolhe o vianjante" (28).

A mesma preocupação aparece em textos de exploradores de origem diversa e que percorreram regiões bem difrentes das que estamos examinando. A presença de espíritos no deserto é um dos perigos mencionados por Marco Polo no seu célebre livro sobre o Oriente. Diz-nos o mais famoso dos viajantes medievais:

"Quando um homem está cavalgando à noite pelo deserto e algo acontece que o faz retardar-se e perder contacto com os seus companheiros, por ter caído no sono ou por alguma outra razão e, depois, quer reunir-se a eles, então ele ouve espíritos falando de maneira que parecem os seus companheiros. De fato, eles, às vezes, até mesmo o chamam pelo nome. Frequentemente, essas vozes fazem-no desviar-se de sua rota de maneira que ele nunca a encontra novamente. $\mathrm{E}$, dessa maneira, muitos viajantes se perderam e morreram. E, às vezes, à noite, eles percebem um barulho semelhante ao de uma grande cavalgada longe da estrada; e, crendo que se trata de alguns cavaleiros da sua companhia, vão para o lugar de onde vem o barulho e, quando

(27) - op. cit., 416-7 in Parks, op. cit., p. 198.

(28) - Chaucer and the Fifteenth Century in The Oxford History of English Literature, II, 1. Oxford, 1954, p. 41. 
começa a amanhecer, percebem que foram vítimas de uma ilusão e se encontram numa situação difícil. E há os que, cruzando este deserto, viram uma hoste de homens vindo na sua direção e, suspeitando de que se tratava de ladrões, fugiram; assim, tendo deixado a trilha conhecida e não sabendo como retornar a ela, perderam-se irremediavelmente. Sim, e mesmo à luz do dia, os homens ouvem essas vozes de espíritos e, frequentemente, imagina-se estar ouvindo o som de muitos instrumentos, especialmente tambores, e o ruído de armas. Por essa razão, bandos de viajantes decidem manter-se sempre bem próximos uns dos outros. Antes de ir dormir, erguem um marco apontancio para a direção na qual tem de viajar. E, em torno do pescoço de todos os seus animais, fixam pequenos sinos de maneira que, ouvindo o seu som, podem evitar que se afastem da rota" (29).

De todos os viajantes britânicos, o que nos dá o mais completo quadro da violência humana durante as expedições é Geraldo de Barry. A existência de várias referências a esse tipo de imprevisto decorre, em parte, do fato de Geraldo ter registrado as suas viagens em narrativas detalhadas, ao contrário de outros autores, que se limitaram a tratar rapidamente das missões em que eles mesmos ou certos personagens ilustres se envolveram (30). As expedições de Geraldo tiveram um caráter oficial, desde que visavam discutir a sua eleição para um bispado galês e, até mesmo, o problema da independência da Igreja do País de Gales em relação à Sé de Cantuária (31).

Em meados de agosto de 1199, o nosso viajante partiu da abadia de Strathflur e se dirigiu para o Continente, com o objetivo de alcançar Roma. Já no início da jornada, Geraldo perdeu o seu companheiro Ithenard, que após ter sido roubado pelo próprio galeses ainda em Gales, caiu doente e faleceu. Em St. Omer, um outro de seus seguidores, de nome Martim, adoeceu e foi obrigado a retornar a Gales.

Como Filipe, rei de França, e Balduíno, conde de Flandres - este aliado ao rei João, da Inglaterra - estivessem em guerra, Geraldo, com os companheiros galeses que the restavam, mais os peregrinos que foram associados à comitiva para substituir os doentes, desviou-se para leste e cruzou a floresta das Ardenas, região perigosa, frequentada por inúmeros

(29) - The Travels. Penguin Books 1976, p. 101.

(30) - Autor galês, importante par o estudo das viagens medievais, Geraldo de Barry (Giraldus Cambrensis) viveu entre 1146 e 1220. Várias de suas obras são, num certo sentido, o resultado de expedições pelas Ilhas Britânicas e pelo Continente. Assim, por ex., a Topographia Hibernica, a Expurgatio Hibernica, o Itinerarium Cambrense e a Descriptio Cambriae. Quanto à De Rebus a Se Gestis, trata-se de uma autobiografia, a qual foi editada, em inglês, por H. E. Butler, The Autobiography of Giraldus Cambrensis. Londres, 1937.

(31) - Cf. The Cambridge Medieval History, VII, pp. 512-3. 
criminosos. Depois, o viajante galês contornou a Champanha e penetrou na Borgonha, a fim de atingir Besançon, de onde seguiu para o Lago Genebra, na companhia de outros grupos de mercadores e peregrinos. Em meados de novembro - três meses, portanto, após a partida - Geraldo atingia Roma, depois de atravessar o Grande São Bernardo, a Lombardia e a Toscana.

O sacerdote galês fez mais duas viagens a Roma: uma em 1201 sobre a qual estamos muito pouco informados - e outra em 1203 quando, após ter desafiado a Sé de Cantuária foi obrigado a sair clandestinamente da Inglaterra (32).

Nessa ocasião, Geraldo viu-se constrangido a tomar o máximo cuidado no seu caminho para Dover e na travessia da Mancha a fim de não ser des-: coberto e capturado pelos emissários do arcebispo inglês. De Gravelines, nosso viajante seguiu para St. Omer mas, no caminho, tendo-se encontrado com grupos de peregrinos que vinham dessa cidade, ficou sabendo que todos os ingleses, que por lá passavam, eram detidos, roubados e postos na prisão. Amedrontado, Geraldo desistiu temporariamente de St. Omer e desviou-se para o castelo de Challi, situado seis milhas ao norte. No dia seguinte, um certo Alexandre, amigo do viajante galês, guiou-o até a temida cidade, onde ele recebeu o dinheiro que tinha enviado para lá, antes de sair da Inglaterra, e fê-lo tomar o caminho de Douai e Cambrai, cujas estradas eram mais seguras.

Em Douai, Geraldo de Barry permaneceu dois dias; no terceiro, partiu para Cambrai. No trajeto, antes de chegarem a esta cidade, o viajante e seus companheiros tiveram novos problemas pois que, diante deles surgiu um servidor de Nevelon, governador do Artois, que com frequência, atacava os viajantes britânicos, roubando-lhes tudo o que podia. Da mesma maneira procedeu o servidor, o qual, percebendo pelas roupas, que a comitiva galesa procedia das Ilhas Britânicas, decidiu-se a abordá-los e, com ameaças de violência, forçou-os a pagar um pesado resgate.

De Cambrai, o nosso viajante seguiu para Paris e, depois, para Claraval e Cister, cruzou a Borgonha e, mais tarde, atravessou os Alpes, penetrando na Itália. Avisado de que seus inimigos estavam preparando armadilhas contra ele em Parma, Geraldo evitou esta cidade, seguindo diretamente para Bolonha, onde escapou a novas violências, desta vez as preparadas por dois de seus próprios companheiros, os cônegos de Llandaff, que, tendo passado para o campo inimigo, tentaram matá-lo.

(32) - Cf. H. E. Butler, The Autobiography of Giraldus Cambrensis. Londres, 1937, pp. 261 sqq. 
Em Faenza, onde chegou a 22 de dezembro, o peregrino galês viu-se frente a nova dificuldade: a falta de dinheiro. Salvo no momento exato, quando se encontrava na mais angustiante situação, por um elemento do local, Geraldo pôde prosseguir viagem e alcançar Bagno di Romagna, no dia 28 do mesmo mês. Nessa altura, talvez por já estar bem acostumado a todo tipo de perigo e de obstáculo das rotas, decidiu-se a cruzar os Apeninos que, normalmente, atemorizavam os viajantes, uma vez que, além de apresentarem regiôes inteiras cobertas de neve e, portanto, difíceis de transpor, eram um dos abrigos tradicionais de toda espécie de bandidos e malfeitores. Tendo sido bem sucedida essa travessia, Geraldo alcançou Spoleto no fim do mês e Roma a 4 de janeiro.

A viagem de retorno foi igualmente acidentada (33). De Ferentino, onde ficou o papa, Geraldo de Barry seguiu para Roma e, daí, para Bolonha, onde passou a ser assediado pelos credores que exigiam o pagamento das suas dívidas com urgência. Antes de partir, ele tinha pedido emprestada uma alta soma de dinheiro e, agora, em Bolonha, enquanto esperava pela chegada de emissários provenientes da feira de Troyes, receava que o dinheiro, que, em breve, lhe seria entregue, não viesse a ser suficiente para o pagamento da dívida e dos juros correspondentes. Mais ainda, o viajante galês viu-se impossibilitado de obter, em Bolonha, novos fiadores, em virtude de acontecimentos que tinham tido lugar pouco antes da sua chegada. Alguns clérigos, de origem espanhola, tinham sido postos na prisão por não estarem em condições de pagar as dívidas de elementos pelos quais tinham-se responsabilizado e que se mostraram insolventes. O escândalo assustara a população bolonhesa e, a partir cle então, os professores da Universidade e demais cidadãos de prestígio da cidade não mais aceitaram ser fiadores de quem quer que fosse.

Todavia, Geraldo não ficou muito tempo em Bolonha. O principal credor comoveu-se com o profundo desespero a que o viajante se entregou e, dizendo ter confiança na sua honestidade, autorizou-o a partir para Troyes, onde ele deveria obter o dinheiro que seria, então, enviado à Itália para saldar a dívida. Assim, Geraldo seguiu para a famosa feira medieval, acompanhado por alguns homens que lhe tinham sido impostos pelos credores. Atravessou a Lombardia, os Alpes e, quando passava por Châtillon-sur-Seine, já bem perto de Troyes, foi reconhecido como viajante originário das Ilhas Britânicas e detido pelo lugar-tenente da localidade, o qual, ao sair do castelo para encontrar-se com o senescal do duque de Borgonha, cruzou com Geraldo, seus companheiros e os peregrinos que viajavam com ele. Estes eram provenientes de Ruão mas disseram ser habitantes de Gisors, que dependia então do rei da França, e foram li-

(33) - Idem, ibidem. 
berados. De todo o grupo de viajantes, apenas Geraldo e um servidor ficaram retidos em Châtillon.

Todavia, a libertação de Geraldo de Barry não iria demorar muito. Pouco antes da sua chegada a Châtillon, um dos agentes do arcebispo de Cantuária, chamado João de Tynemouth, o qual, juntamente com Roberto Balbus, tinha batalhado pela vitória da causa do primaz inglês junto à Cúria, usando inclusive de dinheiro, fora aprisionado e entregue ao senescal do duque de Borgonha. Quando este ficou sabendo, por intermédio de Geraldo, que Tynemouth era um homem de posses e que defendia os interesses de uma autoridade eclesiástica tão destacada, percebeu o proveito que poderia tirar da situação. No dia seguinte, Geraldo foi informado de que estava livre e que podia partir. Após um confronto entre o agente inglês e o viajante galês, quando então os dois tiveram a oportunidade de dizer pessoalmente o que pensavam da maneira como as negociações das duas Igrejas vinham sendo conduzidas junto a Roma - o que the serviu como oportuno desabafo -, Geraldo seguiu para a feira de Troyes. Lá obteve dinheiro suficiente para pagar as dívidas contraídas em Bolonha e, resolvido esse problema, tomou o caminho de Paris. Nesta cidade, encontrou-se com o arcebispo de Dublin, que estava exilado em virtude de desentendimentos surgidos na Igreja Irlandesa, e que, tendo grande estima por Geraldo e percebendo que ele estava novamente em dificuldades financeiras, emprestou-lhe uma boa soma em dinheiro e organizou uma escolta para acompanhá-lo pela Normandia. Assim protegido, o viajante galês chegou a Ruão, onde entrou em contacto com o bispo de Ely, que também acabava de chegar a essa cidade e, dias depois, cruzou a Mancha com destino ao País de Gales.

Em 1204, Geraldo de Barry fez uma terceira visita à Itália. Tendo em vista que, a essa altura, o arcediago galês já tinha abandonado os seus sonhos de estabelecer uma Igreja independente em Gales, essa viagem foi apenas uma peregrinação. Em 1205, Geraldo chegou a Roma e, lá dedicoul-se a obter o maior número possível de dias de indulgência para os seus pecados. Após totalizar 92 dias, alistou-se no Hospital do Espírito Santo, organizado pelo papa Inicêncio III e comumente chamado de Escola Inglesa, onde o seu trabalho fez esse número elevar-se a 100.

Em sinal de arrependimento pelas controvérsias que tinha levantado no passado, Geraldo cedeu ao papa todos os seus benefícios eclesiásticos. A seguir, recebeu-os de volta, o que significava que o pontífice o perdoava e que ele poderia considerar-se, daquele momento em diante, em paz com a Igreja. Estava feita, portanto, a sua reconciliação com Roma. Preocupado em limpar-se de todos os pecados, Geraldo tomou parte, ainda, em orações coletivas e em missas celebradas em diversas igrejas da cidade (34).

(34) - Idem, ibidem. 
Com a viagem de 1204 , terminaram as aventuras italianas daquele que, além de ter deixado um retrato da sociedade galesa de seu tempo, foi o autor dos mais detalhados relatos de viagem a Roma. Geraldo é, sem dúvida, o viajante mais interessante para o estudioso das condições materiais das viagens à Itália. Graças a ele, podemos ter uma visão bastante nítida dos perigos das estradas, dos encontros com amigos e dos socorros que estes poderiam trazer e dos mecanismos de transmissão de dinheiro. As narrativas desse galês incansável são, sem favor, a melhor dentre as obras da literatura de viagem produzida nas Ilhas Britânicas na Idade Média.

Detalhados ou superficiais, os relatos dos viajantes medievais não diferem muito no que diz respeito ao retrato que apresentam das condições materiais em que essas expediçes se realizavam. Se, aqui e alí, aparecem menções aos recursos de que se podia lançar mão no trajeto, tais como hospedaria à beira de estradas, especcialment nas rotas mais frequentadas e nas passagens entre as montanhas, e auxílio financeiro de amigos com os quais se cruzava no caminho, de uma maneira geral, os textos insistem mais nos aspectos negativos das viagens. Na maioria dos casos, a descrição das missões não vai além de uma enumeração de contratempos e de angústias, - estas variando da simples falta de conforto à ameaça de morte suportados com paciência e resignação pelo peregrino. ,

Com certeza, o homem medieval não ficou totalmente insensível à beleza da natureza, aos encantos das diversas cidades e à variedade das populações e de seus costumes; todavia, a concepção de viagem como peregrinação, que é um dos elementos da mentalidade da época, impedia-o de enxergar muito além das aflições quotidianas do caminho, do objetivo do seu esforço e do proveito decorrente dele. Na Idade Média, a viagem nunca é retratada como prazer. Se o foi para alguns viajantes, não é apresentada assim nos textos, onde a realidade sempre era ajustada à atmosfera mental predominnte. Só em 1580, em plena Idade Moderna, é que surge a primeira obra onde a alegria de viajar aparece nitidamente delineada. Trata-se do Journal de Voyage en Italie, de Michel de Montaigne. Nela não encontramos mais o homo viator, sempre a caminho de uma Jerusalém que só pode ser alcançada numa outra existência. O novo viajante, que surge das ruínas do mundo medieval, é o que, curioso e maravilhado, busca conhecer, sempre mais, "o grande livro do Mundo".

Foram as águas medicinais de Plombières, de Baden e, muito especialmente, de Lucca e de Pisa que atraíram Montaigne para a Alemanha e a Itália. Dessa viagem, o autor dos Ensaios deixou um diário relativamente longo, que foi redigido no caminho por um doméstico, ao qual Montaigne ditava as suas impressões todas as noites. Em certas passagens, o servidor substitui inteiramente o famoso escritor e chega a falar dele na terceira pessoa. 
Pouco conhecido até 1774 , ano de sua publicação, o Journal foi objeto de severas críticas de todos aqueles que, acostumados com a imagem estereotipada de um Montaigne cético, isolado do mundo, e dedicado ao polimento da sua grande obra, não puderam aceitar aquele itinerario frio e seco,

“... que não têm maior mérito do que nos informar, com todos os detalhes, como o nosso filósofo encontrou todas as águas e todos os remédios que tomou nas suas diferentes pasagens pela Itália e Alemanha..." (35).

Outros preferiram reservar os seus ataques à indiferença do autor pelas maravillhas artísticas do Renascimento. Stendhal é um dos que se escandalizam com esse fato. Ele lembra que, quando Montaigne passou pela Itália, em busca de tratamento e de distração, as obras de Miguel Ângelo, por ex., constituíam extraordináária novidade pois que o grande gênio florentino tinha morrido há apenas 17 anos.

"... a fama de suas obras repercutia por toda parte, os afrescos divinos de Andrea del Serto, de Rafael e de Correggio estavam em todo o seu frescor. No entanto, Montaigne, esse homem de espírito tão curioso, tão aberto, não diz uma palavra..." (36).

Naturalmente, ao lado dos detratores, surgiram os advogados do trabalho, os quais, por vezes, exagerando, no sentido contrário, chegaram a ver, nele, qualidades que ele não possui. O Journal se insere na longa série de narrativas de viagens medievais e modernas que dão ao leitor, uma série de informações sobre os lugares, sem que as impressões e as emoções do autor se revelem claramente. Assim como a Voyage d'Ogier d'Anglure ou a Cosmografia de Muenster, o diário de Montaigne é um relato minucioso mas, com frequência, bastante impessoal.

De qualquer maneira, é nessa obra que encontramos a primeira manifestação evidente do prazer de viajar. Ela surge na passagem do diário que registra a visita de Montaigne a Roveretto, logo após ter ele entrado na Itália. São dois parágrafos, escritos por seu secretário, nos quais foi traçado um verdadeiro retrato da personalidade do grande escritor. O servidor revela uma sincera admiração por esse doente que esquece a sua moléstia e parte, com alegria, para uma nova etapa de viagem. Mas ele mostra também que esse prazer de viajar não era partilhado pelos companheiros de Montaigne. M. Cazalis tem pressa de chegar a Pádua, onde permanecerá, e M. Mattecoulon esforça-se por alcançar Roma rapidamente a fim de aperfeiçoar-se no uso de armas. O servidor do escritor, autor da passagem, acreditava que, se Montaigne estivesse sozinho,

(35) - Grimm, cit. por P. Michel in M. de Montaigne, Journal, p. XV.

(36) - Promenades aans Rome; ibıdem, p. XVI. 
"ele teria preferido ir a Cracóvia ou à Grécia por terra a tomar a direção da Itália; mas o prazer que sentia em visitar terras desconhecidas, que era tão grande, a ponto de fazê-lo esquecer a franqueza da sua idade, ele não podia transmitir a ninguém do grupo, porque todos só pensavam em descanso. Mesmo após passar uma noite inquieta, quando, pela manhã, ao se lembrar que ia ver uma cidade ou uma nova região, ele se levantava com disposição e alegria (...) Quando os companheiros se queixavam de que, frequentemente, ele conduzia o grupo por complicados caminhos, a ponto de, às vezes, fazê-los aproximar-se do local de onde tinham partido $(\ldots)$, ele respondia que (...) não tinha outro projeto senão visitar lugares desconhecidos $(\ldots)$. Sentia tanto prazer em viajar que chegava a detestar a proximidade do lugar onde deveria repousar e enumerava vários projetos de viagem de sua preferência que gostaria de realizar sozinho" (37).

Que diferença dos textos medievais! Aqui não encontramos nem a obstinada preocupação em atingir o objetivo final da viagem nem a enumeração das dificuldades materiais e violências. O viajante Montaigne sente prazer em conhecer as pequenas localidades em detrimento das grandes cidades; o gosto pela descoberta de lugares interessantes fá-lo esquecer todos os incômodos e, até mesmo, a sua própria doença; e a viagem de tal modo o interessa e entretém que o seu fim não é desejado. Estamos, portanto, diante de uma atitude radicalmente oposta à do homem medieval. Podemos mesmo afirmar que com o Journal de Voyage en Italie, as viagens deixam de ser encaradas exclusivamente como peregrinações. A partir do séc. XVI, viagens e peregrinações não mais se confundem. Se estas últimas continuam a existir, mesmo em pleno mundo contemporâneo, é num sentido restrito, como uma espécie partictlar de viagem, com características especiais, que perpetuam as atitudes e as práticas do homem medieval.

(37) - Journal, pp. 164-6. 